\title{
Electronic Money and Consumer Spending Behaviour: Evidence from Ghana
}

\author{
Michael N.A. Mensah ${ }^{1}$ and Adusei Jumah ${ }^{2}$
}

\begin{abstract}
This study examines how e-money usage affects consumer spending behaviour through discrete choice analysis considering demographic characteristics. It also assesses people's attitudes towards the challenges and benefits of using e-money through ANOVA. Our analyses indicate that e-money significantly impacts consumer spending behaviour, with the type of e-money and the expenditure made with e-money both influencing the consumers' expenditures. Gender, age, and employment status also affected consumers' spending behaviour as expected. However, the length of e-money usage had no effect. Interestingly, the respondents' challenges associated with using e-money had no significant effect on the frequency of e-money usage. On the contrary, the derived benefits of using e-money had significant effects.
\end{abstract}

JEL classification numbers: C25, D12, E42.

Keywords: Electronic money, Consumer behaviour, Discrete choice, Ordered logit.

1 Department of Economics, Central University, Ghana.

2 Department of Economics, Central University, Ghana.

Article Info: Received: March 21, 2021. Revised: April 15, 2021.

Published online: April 25, 2021. 


\section{Introduction}

The European Central Bank (ECB, 1998) defines electronic money as an electronic store of monetary value on a technical device that may be widely used for making payments to undertakings other than the issuer without necessarily involving bank accounts in the transaction but acting as a prepaid bearer instrument. Electronic money is a cost-effective alternative to cash for small value transactions and it serves as a convenient medium of sending and receiving money over the internet (Papadopoulos, 2007). Thus, even though cash and cheque are still prevalent in some parts of the world, electronic payment mechanisms, especially mobile payments, have become accepted by consumers and vendors in many economies due to the high penetration of mobile phone technology (Khan and Craig-Lee., 2009).

Money has always adapted to the different economic conditions. The forms that money has taken on over the centuries have always been closely connected with the technological developments in the economy. Vlasov (2017) argues that the concept of electronic money existed thousands of years ago and that the modern electronic money system is only an advanced version of the thousand-year-old technology. Apart from its convenience and safety, electronic money also has a significant number of economic benefits, which include mobilizing savings and ensuring that most of the cash available in the country is with financial institutions or banks (Okifo and Igbunu, 2015). This will make funds available to borrowers-both businesses and individuals. Furthermore, an electronic payment system has the ability to track individual spending to facilitate the design of products by the banks. This information could be useful to the government and central bank when making decisions.

Evidently, consumers today have the choice to pay for transactions with an increasingly growing range of payment mechanisms. Different payment methods induce different spending behaviour of consumers. Cash payment makes it easier to control spending than electronic payment. Thus, frugal consumers would prefer to make payment with cash in order to control their spending (Runnemark, Hedman and Xiao, 2015). On the other hand, Trütsch (2014) has shown that the adoption of electronic money payment systems has led to increased consumer spending. Transactions become relatively cheaper with the use of electronic money. This stimulates a rise in the number of transactions and an increase in the velocity of money (Popoyska-Kamnar, 2014). Arguably, the use of electronic money engenders impulse buying.

More recently, the Bank of England Governor Andrew Bailey indicated that digital innovation in payments is here to stay (Nelson, 2021). Tesla also lately purchased $\$ 1.5 \mathrm{bn}$ of Bitcoin and announced it will start accepting the cryptocurrency as payment (BBC, 2021). Meanwhile, the ECB and the national central banks of the euro area are exploring the benefits and risks of a digital euro so that money continues to serve Europeans well (ECB, 2020). And the Fed Chair Powell says that a digital dollar is a 'high priority project' (Hansen, 2021). Whereas the deepening 
and widening of electronic money systems in the developed countries continue at a rapid pace, progress is comparatively slow in developing countries because too many of their citizens do not have access to easy payments systems and banking accounts. Expansion in developing countries would require two things, among others: An understanding of how electronic money usage affects their citizens' spending behaviour and the perceptions of their citizens towards the challenges and benefits associated with its usage.

A great deal of research conducted on electronic money explore how the various systems of electronic money operate (e.g., Ito et al., 2000; Kawashima et al., 2004; Oskolkov et al., 2013; among copious others). A substantial number of papers also focus on the privacy and security issues associated with the use of electronic money (e.g., Yacobi, 1996; Hanáček, 1998; Islam, 2015). Others focus on the impact that electronic money has on the monetary system-more specifically whether electronic money poses a threat to the ability of central banks to control the value of their national currencies through conventional monetary policy (Woodford, 2000), or the implications of the introduction of electronic money for the future of central banks and monetary policy effectiveness as a whole (e.g., Freedman, 2000; Cohen, 2001; Bandiera, 2004, Al-Laham, 2009; Popovska-Kamnar, 2014).

Increasingly, a strand of papers is focusing on how electronic money affects consumer behaviour; more precisely consumer spending (e.g., Gan et al., 2006; Khan et al., 2009; Jack et al., 2010; Maurer, 2012; Bayero, 2015). These papers mostly focus on one or two forms of electronic money-electronic banking (Gan et al., 2006); mobile money (Khan et al., 2009; Jack et al., 2010; Vincent et al., 2011; Maurer, 2012; Evans et al., 2014; Balasubramanian, 2015); credit card (Calem and Mester, 1995; Hirschman, 1979; Ahmed et al., 2010); debit card (Singla and Bansal, 2015; Bauer and Masella, 2008); both credit card and debit card (Del Bene et al., 2019; Maitland et al., 2010; Foscht et al., 2010); smart card (Afrifa-Mintah, 2016); $e$-wallet (McClung III, 2016; Aji et al., 2020; Lan et al., 2020). In developing countries where electronic money is gradually surfacing (Rotman, 2014), a great deal of the literature is centred on mobile money.

While most papers focus on one or two forms of electronic money, our empirical analysis labels the various electronic money forms as "electronic money" and we analyse their effects on the spending behaviour of their users in Accra, taking demographic characteristics into consideration. In this regard, we follow the approach of Jack et al. (2010) that is based on the Kenyan experience with electronic money vis-à-vis the effects M-PESA (a mobile banking system in Kenya) have on its users. However, unlike Jack et al. (2010), who employed the Townsend Model of Financial Deepening and Growth, we used ordered logit. Another objective of the study is to assess the benefits and challenges of e-money to the consumer. We assume Accra to be representative of Ghana and this could be a limitation of the study. Nevertheless, the Accra metropolis is the largest and most cosmopolitan urban area in Ghana and thus characterizes the country's distinct demographic differences (see also Jumah et al., 2008).

The organization of the paper is as follows: Section 1 is a general introduction. 
Section 2 expounds the model and data employed in the study; Section 3 interprets the empirical results and Section 4 concludes.

\section{Methodology}

\subsection{Discrete Choice Theory}

The theory of consumer choice has been the backbone of determining most consumer behaviour characteristics by linking the consumer's preference to their expenditure and demand with a budget constraint. A buildout of this is the discrete choice theory that examines economic situations on a wider scope factoring the randomness and specificity of the environment in each economic situation. Aloulou (2018) argues that discrete choice theory overcomes the rigidities and inadequacies of the study of consumer behaviour. Pioneered by McFadden in Domencich and McFadden (1975), discrete choice models have been employed to analyse, for example, preferred modes of transport (e.g., Ben-Akiva et al., 2018; Brownstone, 2001; Horne et al., 2005; Washbrook et al., 2006), as well as product differentiation (e.g., Anderson et al., 1992; Berry, 1994). In recent times, the discrete choice model has also proven instrumental in health economics to address a wide range of health policy-related concerns (e.g., Clark et al., 2014; Ryan, 2004).

As in the studies on choice of transport mode or product differentiation, we employ discrete choice theory rather than traditional consumer choice theory because our dependent variable (consumer spending) was categorized into levels. In particular, the discrete choice model allows us to explore how the type of electronic money and the frequency of its usage affect consumer spending with the aid of the ordered logistic regression model. Consumer preference analysis by means of discrete choice is based on probability regression models (Bąk and Rybicka, 2005). The ordered logistic regression model is a probability regression model, best suited for ordinal outcome variables rather than continuous outcome variables (Williams, 2016) and as such can be used for empirical analysis of discrete choice. The outcome variables in our study are ordinal, making the ordered logistic model the best fit for our study.

\subsection{The Ordered Logit Model}

This study examines how the type and usage of electronic money affect consumer spending, in the light of demographic characteristics by means of a discrete choice model. Our model is only applicable to data that meets the proportional odds assumption. The dependent variable-consumer spending-is ordered into low, medium, and high categories. Grilli et al. (2014) suggest that when the response variable of interest is ordinal, it is advisable to use a specific model such as the ordered logit. The ordered logit model is an extension of logistic regression. Whilst the logistic regression is applicable to only dichotomous dependent variables, the ordered logit permits the use of more than two ordered responsive categories. 
Our final model is represented in the form:

$$
y^{*}=X \beta+\varepsilon
$$

The dependent variable (consumer spending) represented by y, is made up of 3 ordered discrete variables (low, medium, and high). The unobservable dependent variable $\mathrm{y}^{*}$ is the latent variable corresponding to consumer spending $(\mathrm{y}) . X$ consists of 6 independent variables - gender, age, employment status, type of e-money, expenditure using e-money, length of e-money usage, $\beta$ is the corresponding parameter to be estimated, and $\varepsilon$ is the error term subject to logistic distribution.

Let $\alpha_{1}<\alpha_{2}<\alpha_{3}$ represent the estimated critical value and the relationship between $y^{*}$ and $y$ depends on whether it is greater than or less than the given critical value such that:

If $\mathrm{y}^{*} \leq \alpha_{1}$ represents low, $\mathrm{y}=1$

If $\alpha_{1}<y^{*} \leq \alpha_{2}$ represents medium, $y=2$

If $\alpha_{2}<y^{*}$ represents high, $y=3$.

Thus, given the independent variable $x$, the response probability $\mathrm{p}$, of the dependent variable $Y$ at each value can be calculated as:

$$
\left\{\begin{array}{l}
\mathrm{p}(\mathrm{y}=1)=\mathrm{p}\left(y^{*} \leq \alpha_{1}\right)=\mathrm{p}\left(\mathrm{X} \beta+\mathrm{u} \leq \alpha_{1}\right)=\phi\left(\alpha_{1}-\mathrm{X} \beta\right) \\
\mathrm{p}(\mathrm{y}=2)=\mathrm{p}\left(\alpha_{1}<y^{*} \leq \alpha_{2}\right)=\phi\left(\alpha_{2}-\mathrm{X} \beta\right)-\phi\left(\alpha_{1}-\mathrm{X} \beta\right) \\
\mathrm{p}(\mathrm{y}=3)=\mathrm{p}\left(y^{*}>\alpha_{2}\right)=1-\phi\left(\alpha_{3}-\mathrm{X} \beta\right)
\end{array}\right.
$$

Where $\phi$ is the cumulative distribution function of the standard normal distribution.

\subsection{ANOVA}

Other objectives of the study were to assess the benefits and challenges of e-money to the consumer. Questions were raised in questionnaires to address these objectives. Analysis of Variance (ANOVA) tests were subsequently carried out (Eriksson et al, 2008) to analyze the statistical significance of the ensuing responses. ANOVA which relies on the $\mathrm{F}$ statistic for inference, focuses on the difference of variances (Kim, 2017) and this makes it our preferred choice of statistical technique since our main concern is to test for the statistical significance between two variables. Specifically, we found a one-way ANOVA to be suitable for our analysis as it employs one independent variable with two or more levels and one dependent variable (Horn, 2008).

E-money usage is picked as our dependent variable because it measures how frequent the respondent uses e-money. The benefits comprised of time saving, less risky money as compared to fiat money, user friendly and convenient. The various challenges were security, privacy, interoperability, legal framework, technical infrastructure, high demand by customers, cost for customers and cost for issuers. These challenges and benefits were individually tested as independent variables against the dependent variable using the one-way ANOVA test. 


\subsection{Method of Data Collection}

We employ the mixed method research approach that is characterized by a combination of quantitative and qualitative methods within a single study (Agerfalk, 2013) to retrieve the relevant data. According to Creswell (2016), qualitative procedures stand in stark contrast to the methods of quantitative research. Quantitative inquiry uses diverse knowledge claims, inquiry approaches and data collection methods and analysis whilst qualitative procedures depend on the text and image data, although the procedures are similar.

The data on electronic money was gathered through a series of interviews of 150 individuals from February 2019 to April 2019. Out of individuals, a sample size of 99 was obtained the data was cleaned. Random but purposeful sampling procedure was used in the selection of the respondents. To qualify as a respondent, a person must have any form of electronic money. The respondents included office workers, shop owners, students, and housewives.

Questionnaires were generated to extract information on individual characteristics and individuals' usage of the respective types of electronic money as well as monthly expenditure, monthly income and experience with electronic money i.e., benefits and challenges. The individual characteristics identified included the agerange, sex, marital status, occupation as well as educational status.

\section{Results and Discussion}

\subsection{Demographic Characteristics}

Results from the survey as represented in Table 1, revealed that $65 \%$ of the respondents identified as males whilst $35 \%$ were females, making the findings of the survey more attributable to the male respondents than the female respondents. Also, about $82 \%$ of the respondents were in the 20 to 40 year-group, whilst $64 \%$ were in the 20 to 30 year-group. This is not surprising as a priori; one would expect the youth and adults to adapt to technology faster (Hanson, 2010). 
Table 1: Distribution of Gender and Age of Respondents

\begin{tabular}{|c|l|c|c|}
\hline Demographics & \multicolumn{1}{|c|}{ Categories } & Frequency & Percent (\%) \\
\hline \multirow{4}{*}{ Gender } & Male & 64 & 65 \\
\cline { 2 - 4 } & Female & 35 & 35 \\
\hline \multirow{5}{*}{ Age } & Total & $\mathbf{9 9}$ & $\mathbf{1 0 0}$ \\
\hline \multirow{5}{*}{} & Below 20 years & 4 & 4 \\
\cline { 2 - 4 } & 20 years & 45 & 46 \\
\cline { 2 - 4 } & 30 years & 19 & 19 \\
\cline { 2 - 4 } & 40 years & 18 & 18 \\
\cline { 2 - 4 } & 50 years and above & 12 & 12 \\
\hline & Total & $\mathbf{9 9}$ & $\mathbf{1 0 0}$ \\
\hline
\end{tabular}

Source: Field Survey 2019

In addition, Table 2 shows that nearly $60 \%$ of the respondents identified as singles, $32 \%$ as married, $7 \%$ were divorced and $2 \%$ identified as widowed. The percentage of respondents who identified as employed constituted $66 \%$ of the respondents, $27 \%$ identified as students and 7\% identified as unemployed. This suggests that most of the respondents are employed. Also, 74\% identified as having at least tertiary level of education, $7 \%$ have secondary education whiles $18 \%$ have professional education. All this indicated a very high level of educated respondents. 
Table 2: Distribution of Marital Status, Employment Status and Educational Background of Respondents

\begin{tabular}{|c|l|c|c|}
\hline Demographics & \multicolumn{1}{|c|}{ Categories } & Frequency & Percent (\%) \\
\hline \multirow{4}{*}{ Marital Status } & Single & 58 & 59 \\
\cline { 2 - 4 } & Married & 32 & 32 \\
\cline { 2 - 4 } & Divorced & 7 & 7 \\
\cline { 2 - 4 } & Widowed & 2 & 2 \\
\cline { 2 - 4 } & Total & $\mathbf{9 9}$ & $\mathbf{1 0 0}$ \\
\hline \multirow{5}{*}{ Employment Status } & Employed & 65 & 66 \\
\cline { 2 - 4 } & Unemployed & 7 & 7 \\
\cline { 2 - 4 } & Students & 27 & 27 \\
\hline \multirow{5}{*}{ Educational Background } & Total & $\mathbf{9 9}$ & $\mathbf{1 0 0}$ \\
\cline { 2 - 4 } & Professional & 18 & 18 \\
\cline { 2 - 4 } & Tertiary & 74 & 75 \\
\cline { 2 - 4 } & Secondary & 7 & 7 \\
\hline & Total & $\mathbf{9 9}$ & $\mathbf{1 0 0}$ \\
\hline
\end{tabular}

Source: Field Survey 2019

From Table 3, 50\% identified mobile money as their preferred choice for e-money transactions, 22\% identified debit card as their preferred choice for e-money, 15\% preferred credit card transactions and 13\% prefer internet banking. This suggests that majority of the respondents prefer mobile money for their e-money transactions.

Table 3: Distribution of Respondents Views on the Types of E-money

\begin{tabular}{|l|c|c|}
\hline \multicolumn{1}{|c|}{ Type of E-Money } & Frequency & Percent (\%) \\
\hline Mobile money & 49 & 50 \\
\hline Debit card & 22 & 22 \\
\hline Credit card & 15 & 15 \\
\hline Internet banking & 13 & 13 \\
\hline Total & $\mathbf{9 9}$ & $\mathbf{1 0 0}$ \\
\hline
\end{tabular}

Source: Field Survey 2019 


\subsection{Ordered Logit Analysis}

As discussed at length in Section 2, the expenditure variable, i.e., the dependent variable, was ordered into low, medium, and high expenditure settings to run the model as an ordered logistic regression. The low expenditure being the lowest order represents expenditure below Ghc1000, medium representing the second order from Ghф1001 to Ghф5000, and finally high representing the highest order which is expenditure above Gh $\varnothing 5000$. Low expenditure was the most frequent response accounting for about 55\% of the response, medium accounted for $39 \%$ of the response, and $6 \%$ accounted for high expenditure.

The results of the ordered logistic regression and average margins are shown in Table 4 below.

Table 4: The Estimated Probabilities and Marginal Effects

\begin{tabular}{|l|c|c|}
\hline \multicolumn{1}{|c|}{ Variables } & (1) & (2) \\
\hline Gender & Exp & Marginal effects \\
\hline & $-2.168^{* * *}$ & $0.155^{* * *}$ \\
\hline Age & $(0.826)$ & $(0.0534)$ \\
\hline & $1.344^{* * *}$ & $-0.0959^{* * *}$ \\
\hline Employment status & $(0.367)$ & $(0.0196)$ \\
\hline & $-1.458^{* *}$ & $0.104 * *$ \\
\hline Length of e-money usage & $(0.635)$ & $(0.0420)$ \\
\hline & -0.473 & 0.0337 \\
\hline Type of e-money & $(0.331)$ & $(0.0224)$ \\
\hline & $0.809 * *$ & $-0.0577 * *$ \\
\hline Expenditure using e-money & $(0.367)$ & $(0.0234)$ \\
\hline & $4.604 * * *$ & $-0.329 * * *$ \\
\hline Constant cut1 & $(1.016)$ & $(0.0535)$ \\
\hline & $6.015 * * *$ & \\
\hline Constant cut2 & $(1.950)$ & \\
\hline & $15.57^{* * *}$ & \\
\hline Observations & $(3.418)$ & \\
\hline
\end{tabular}

Standard errors in parentheses

$* * * \mathrm{p}<0.01, * * \mathrm{p}<0.05$

In view of the nature of this study, our interpretation will be inferred from both the results derived from the coefficients of the ordered logistic regression and those of the marginal effects analyses. While the coefficients of the ordered logistic 
regression show the ordered log-odds estimate (odds ratio) of the dependent variable as a result of a one unit increase in the predictor variable holding the others constant, the marginal effects coefficients reveal to us the predicted increment of the dependent variable associated with a unit increase in one of the covariates while holding the others constant (Anderson and Newell, 2003; Norton et al., 2004). The signs of the coefficients, however, are used to determine whether there was an increase or decrease given that the marginal effects change the signs (Ai and Norton, 2003). From Table 4, only one of the six predictor variables is statistically insignificant. Of the significant variables, two had negative coefficients whilst three had positive coefficients.

Gender and employment status both had negative effects on the monthly expenditure. The gender variable was coded 0 for male and 1 for female. Hence, from the table, the ordered log-odds estimate for a female's expenditure is 2.17 levels lower than that for a male. This is in line with findings from Baah-Boateng (2012) that suggest the existence of discrimination in the Ghanaian labour market, with men earning significantly higher wages than women. Also, from the table, the employment status shows that the ordered log odds for a student's expenditure is 1.46 levels lower than an employed respondent and 1.46 levels higher than an unemployed respondent.

Age, and expenditure using e-money all have positive effects on the respondent's expenditure. The results for age suggest that a unit increase in the respondent's age which in this case is 10 years, has a marginal effect of $9.6 \%$ increase in their monthly expenditure and an ordered log odds estimate of a 1.34 level increment in their monthly expenditure.

The outcome for the type of e-money used is more concerned with how a change in the type of electronic money tool used may affect the respondent's monthly expenditure. From the table, the mere choice of a respondent's electronic money tool has a 5.8\% marginal effect on the respondent's monthly expenditure. Length of e-money usage had no effect on monthly expenditure 


\subsection{ANOVA}

\subsubsection{Challenges Associated with E-Money Usage}

The ANOVA results from the respondents' attitude towards the challenges associated with the use of electronic money are presented in Tables 5.

Table 5: ANOVA Results for the Challenges attributed to E-Money Usage

\begin{tabular}{|l|c|c|}
\hline \multicolumn{1}{|c|}{ Challenges } & F-statistic & P-value \\
\hline Security & 1.36 & 0.246 \\
\hline Privacy & 0.16 & 0.687 \\
\hline Interoperability & 0.18 & 0.675 \\
\hline Legal framework & 0.10 & 0.754 \\
\hline Technical infrastructure & 0.11 & 0.739 \\
\hline High demand by customers & 0.03 & 0.860 \\
\hline Cost for customers & 0.05 & 0.819 \\
\hline Cost for issuers & 0.01 & 0.920 \\
\hline
\end{tabular}

Source: Field Survey 2019

The table clearly shows that the challenges faced by the respondents has no significant $(\mathrm{P} \leq 0.05)$ effect on how often the respondents use e-money. Security being the most selected obstacle obtained an F statistic of 1.36 and a level of significance of 0.246 . This postulates that the challenge(s) faced by the respondents has/have no significant effect on their use of e-money.

\subsubsection{Benefits Associated with E-Money Usage}

The respondents' perceptions towards the benefits of the usage of electronic money are presented in Table 6 . The respondents were asked to agree or disagree with some benefits associated with the use of e-money. According to the table, $92 \%$ of the respondents agree to e-money being convenient, $79 \%$ of respondents agree that emoney is less risky than fiat money, i.e., notes and coins. $90 \%$ of the respondents agree to e-money being user-friendly, and $92 \%$ of respondents agree that e-money saves them time. The majority of the respondents agree with the benefits associated with the use of e-money. 
Table 6: ANOVA Results for the Benefits Associated with E-Money Usage

\begin{tabular}{|c|c|c|}
\hline Benefits of E-money & F-statistic & P-value \\
\hline Time saving & 12.74 & $0.000 * * *$ \\
\hline Less-risky compared to fiat money & 3.82 & $0.050 * *$ \\
\hline Convenient & 12.74 & $0.000 * * *$ \\
\hline User friendly & 9.69 & $0.002 * * *$ \\
\hline $\mathrm{p}<0.01, * * \mathrm{p} \leq 0.05$ & & \\
\hline
\end{tabular}

Source: Field Survey 2019

From Table 6, it is unequivocal that the benefits of using e-money have a significant $(\mathrm{P} \leq 0.05)$ effect on how often the respondents use e-money. This meets a priori expectations. Aside the benefit of being less risky compared to fiat money which has an F-statistic of 3.82 and a P-value of 0.05 , making it a significant benefit, all the other benefits obtained a P-value of 0.00 , making them highly significant to affecting the respondents' use of e-money. In contrast to the challenges, the benefits seem to be the driving forces behind the use E-Money.

\section{Conclusions and Recommendations}

In recent years, technology has transformed our way of life and how we trade is no exception. Electronic money is gradually taking over fiat money, and the inroads are envisaged to affect consumer behaviour. This study examines how electronic money usage affects consumer spending behaviour in light of demographic characteristics. It also assesses people's attitudes towards the challenges and benefits of the usage of electronic money.

Our analyses indicate that electronic money does indeed significantly impact consumer spending behaviour with the type of electronic money and the expenditure made with electronic money both influencing consumers' expenditures. Gender, age, and employment status also affected consumers' spending behaviour as expected. However, the length of electronic money usage had no effect.

Interestingly, the respondents' challenges associated with using e-money had no significant effect on the frequency of electronic money usage. On the contrary, the derived benefits of using e-money had significant effects. That the challenges had no significant effects on electronic money usage should not be an incentive for manufacturers of e-money apps to neglect these challenges. Helping consumers overcome these challenges will improve electronic money usage. 


\section{References}

[1] Afrifa-Mintah, K. (2016). The effect of advertising on the purchasing behavior of bank customers A case study of E-zwich. Doctoral Dissertation, School of Business, Kwame Nkrumah University of Science and Technology, Kumasi.

[2] Ågerfalk, P. J. (2013). Embracing diversity through mixed methods research. European Journal of Information Systems, 22(3), 251-256.

[3] Ahmed, Z. U., Ismail, I., Sohail, M. S., Tabsh, I., and Alias, H. (2010). Malaysian consumers' credit card usage behavior. Asia Pacific Journal of Marketing and Logistics, 22(4), 528-544.

[4] Ai, C., and Norton, E. C. (2003). Interaction terms in logit and probit models. Economics letters, 80(1), 123-129.

[5] Aji, H. M., Berakon, I., and Husin, M. M. (2020). COVID-19 and e-wallet usage intention: A multigroup analysis between Indonesia and Malaysia. Cogent Business \& Management, 7(1), 1804181.

[6] Al-Laham, M., Al-Tarwneh, H., and Abdallat, N. (2009). Development of electronic money and its impact on the central bank role and monetary policy. Issues in Informing Science and Information Technology, 6, 339-349.

[7] Aloulou, F. (2018). The application of discrete choice models in transport. In Statistics - Growing Data Sets and Growing Demand for Statistics, p.85.

[8] Anderson, S. P., De Palma, A., and Thisse, J. F. (1992). Discrete choice theory of product differentiation. MA, Cambridge: MIT Press.

[9] Anderson, S., \& Newell, R. G. (2003). Simplified marginal effects in discrete choice models. Economics Letters, 81(3), 321-326.

[10] Baah-Boateng, W. (2012). Labour market discrimination in Ghana: A gender dimension. Saarbrücken: LAP Lambert Academic Publishing.

[11] Bąk, A., and Rybicka, A. (2005). Application of discrete choice methods in consumer preference analysis. In Innovations in classification, data science, and information systems (pp. 305-312). Springer, Berlin, Heidelberg.

[12] Balasubramanian, K., and Drake, D. F. (2015). Service quality, inventory and competition: An empirical analysis of mobile money agents in Africa (No. 15059). Cambridge, MA: Harvard Business School.

[13] Bandiera, L. (2004). Monetary policy, monetary areas, and financial development with electronic money. DC, Washington: International Monetary Fund, Working Paper No. 04/122.

[14] Bauer, J.L., and Masella, M. (2008). System and method of operating a debit card reward program. U.S. Patent 7,392,224. Washington, DC: U.S. Patent and Trademark Office. JPMorgan Chase Bank NA.

[15] Bayero, M. A. (2015). Effects of Cashless Economy Policy on financial inclusion in Nigeria: An exploratory study. Procedia-Social and Behavioral Sciences, 172, 49-56.

[16] BBC News, (2021) Elon Musk's Tesla buys \$1.5bn of Bitcoin causing currency to spike. BBC. Available at: https://www.bbc.com/news/business55939972. 
[17] Ben-Akiva, M., and Lerman, S. R. (2018). Discrete choice analysis: theory and application to travel demand. Transportation Studies. MA, Cambridge: MIT Press.

[18] Berry, S. T. (1994). Estimating discrete-choice models of product differentiation. The RAND Journal of Economics, 25(2), 242-262.

[19] Brownstone, D. (2001). Discrete choice modeling for transportation. UC, Berkeley: University of California Transport Center. Available at https://escholarship.org/uc/item/29v7d1pk.

[20] Calem, P. S., and Mester, L. J. (1995). Consumer behavior and the stickiness of credit-card interest rates. The American Economic Review, 85(5), 13271336.

[21] Clark, M. D., Determann, D., Petrou, S., Moro, D., and de Bekker-Grob, E. W. (2014). Discrete choice experiments in health economics: a review of the literature. PharmacoEconomics, 32(9), 883-902.

[22] Cohen, B. J. (2001). Electronic money: new day or false dawn? Review of International Political Economy, 8(2), 197-225.

[23] Creswell, J. W., and Poth, C. N. (2016). Qualitative inquiry and research design: Choosing among five approaches.CA, Thousand Oaks: SAGE Publications.

[24] Del Bene, M., Hu, P., Nambiar, A., and Salazar, D. G. (2019). Methods and systems for predicting consumer behavior from transaction card purchases. U.S. Patent 10,430,803. Washington, DC: U.S. Patent and Trademark Office. Mastercard International Inc.

[25] Domencich, T. A., and McFadden, D. (1975). Urban travel demand-a behavioral analysis. Amsterdam: North Holland Publishing.

[26] Eriksson, L., Trygg, J., and Wold, S. (2008). CV-ANOVA for significance testing of PLS and OPLS ${ }^{\circledR}$ models. Journal of Chemometrics: A Journal of the Chemometrics Society, 22(11-12), 594-600.

[27] European Central Bank. (1998). Report on electronic money. European Central Bank.

[28] European Central Bank. (2020). Report on a digital euro. European Central Bank.

[29] Evans, D. S., and Pirchio, A. (2014). An empirical examination of why mobile money schemes ignite in some developing countries but flounder in most. Review of Network Economics, 13(4), 397-451.

[30] Foscht, T., Maloles, C., Swoboda, B., and Chia, S. L. (2010). Debit and credit card usage and satisfaction: who uses which and why-evidence from Austria. International Journal of Bank Marketing, 28(2), 150-165.

[31] Freedman. (2000). Monetary policy implementation: past, present and futurewill electronic money lead to the eventual demise of central banking? International Finance, 3(2), 211-227.

[32] Gan, C., Clemes, M., Limsombunchai, V., and Weng, A. (2006). A logit analysis of electronic banking in New Zealand. International Journal of Bank Marketing. Vol. 24, DOI: 10.1108/02652320610701717. 
[33] Grilli, L., and Rampichini, C. (2014). Ordered logit model. Encyclopedia of quality of life and well-being research, pp 4510-4513.

[34] Hanáček, P. (1998, November). Security of electronic money. In International Conference on Current Trends in Theory and Practice of Computer Science (pp. 107-121). Springer, Berlin, Heidelberg.

[35] Hansen, S. (2021). Fed chair Powell says digital dollar is a 'high priority project,' Forbes Magazine. Available at https://www.forbes.com/sites/sarahhansen/2021/02/23/fed-chair-powell-saysdigital-dollar-is-a-high-priority-project/

[36] Hanson, V. L. (2010). Influencing technology adoption by older adults. Interacting with Computers, 22(6), 502-509.

[37] Hirschman, E. C. (1979). Differences in consumer purchase behavior by credit card payment system. Journal of Consumer Research, 6(1), 58-66.

[38] Horn, R. A. (2008). Understanding the one-way ANOVA. Course handout for Educational Psychology525. Department of Educational Psychology, Northern Arizona University, 2008.

[39] Horne, M., Jaccard, M., and Tiedemann, K. (2005). Improving behavioral realism in hybrid energy-economy models using discrete choice studies of personal transportation decisions. Energy Economics, 27(1), 59-77.

[40] Islam, M. S. (2015). An algorithm for electronic money transaction security (Three Layer Security): A new approach. International Journal of Security and Its Applications, 9(2), 203-214.

[41] Ito, A., and Hiroya, M. (2000). Electronic money sending system. U.S. Patent No. 6,039,250. Washington, DC: U.S. Patent and Trademark Office. Hitachi Ltd.

[42] Jack, W., Suri, T., and Townsend, R. M. (2010). Monetary theory and electronic money: Reflections on the kenyan experience. FRB Richmond Economic Quarterly, 96(1), 83-122.

[43] Jumah, A., Johnson, P. N. T., Quayson, E. T., Tortoe, C., and Oduro-Yeboah, C. (2008). Market testing of a major cassava flour product in the Accra metropolitan area. International Journal of Consumer Studies, 32(6), 687-691.

[44] Kawashima, T., Hagiwara, K., Hayaashi, H., Hasumi, Y., Shiotani, K., and Suganuma, M. (2004). Electronic money system. U.S. Patent Application 10/344,200, Sony Corp.

[45] Khan, J., and Craig-Lees, M. (2009). "Cashless" transactions: perceptions of money in mobile payments. International Business \& Economics Review, 1(1) 23-32.

[46] Kim, T. K. (2017). Understanding one-way ANOVA using conceptual figures. Korean Journal of Anesthesiology, 70(1), 22.

[47] Lan, H. L. T., Van, H. T. T., and Phuong, H. T. T. (2021). Factors Influencing the Intention to Choose E-Wallet in Shopping Online: Case Study of Ha Noi Citizens. In Management for Sustainable and Inclusive Development in a Transforming Asia (pp. 311-326). Springer, Singapore. 
[48] Maitland, J., Murly, T., Walker, D. A., and Rademaker, J. R. (2010). Methods and systems for predicting business behavior from profiling consumer card transactions. U.S. Patent 7,853,469. Washington, DC: U.S. Patent and Trademark Office. Mastercard International Inc.

[49] Maurer, B. (2012). Mobile money: Communication, consumption and change in the payments space. Journal of Development Studies, 48(5), 589-604.

[50] McClung III, G. L. (2016). Digital money choice and eWallet selection, U.S. Patent Application 14/544,199. Guy LaMonte McClung and III.

[51] Nelson, D. (2021). Bank of England governor insists digital payments (but not crypto) are sticking around. CoinDesk Available at: https://www.coindesk.com/andrew-bailey-fiat-crypto-davos

[52] Norton, E. C., Wang, H., and Ai, C. (2004). Computing interaction effects and standard errors in logit and probit models. The Stata Journal, 4(2), 154-167.

[53] Okifo, J., and Igbunu, R. (2015). Electronic payment system in Nigeria: Its economic benefits and challenges. Journal of Education and Practice, 6(16) 5662.

[54] Oskolkov, I., and Shishkov, R. (2013). Electronic money transfer service. U.S. Patent Application 13/226,373, Rawllin International Inc.

[55] Papadopoulos, G. (2007). Electronic money and the possibility of a cashless society. Available at SSRN 982781.

[56] Popovska-Kamnar, N. (2014). The use of electronic money and its impact on monetary policy. Journal of Contemporary Economic and Business Issues, 1(2), 79-92.

[57] Rotman, S. (2014). Bitcoin versus electronic money. CGAP Brief; World Bank, Washington, DC.

[58] Runnemark, E., Hedman, J., and Xiao, X. (2015). Do consumers pay more using debit cards than cash? Electronic Commerce Research and Applications, $14(5), 285-291$.

[59] Ryan, M. (2004). Discrete choice experiments in health care. BMJ (Clinical research ed.), 328(7436), 360-361.

[60] Singla, B., and Bansal, M. (2015). Consumers behavior towards debit card payment mode while shopping at retail stores. Research Cell: An International Journal of Engineering Sciences, 16(1), 121-126.

[61] Trütsch, T. (2014). The impact of contactless payment on spending. International Journal of Economic Sciences, 3(4) 70-98.

[62] Vincent, K., and Cull, T. (2011). Cell phones, electronic delivery systems and social cash transfers: Recent evidence and experiences from Africa. International Social Security Review, 64(1), 37-51.

[63] Vlasov, A. V. (2017). The evolution of e-money. European Research Studies, 20(1), 215-224.

[64] Washbrook, K., Haider, W., and Jaccard, M. (2006). Estimating commuter mode choice: A discrete choice analysis of the impact of road pricing and parking charges. Transportation, 33(6), 621-639. 
[65] Williams, R. (2016). Understanding and interpreting generalized ordered logit models. The Journal of Mathematical Sociology, 40(1), 7-20.

[66] Woodford, M. (2000). Monetary policy in a world without money. International Finance, 3(2), 229-260.

[67] Yacobi, Y. (1996). Efficient electronic money. U.S. Patent 5,511,121. Washington, DC: U.S. Patent and Trademark Office. Telcordia Technologies Inc. 